\title{
TIME, DREAMS AND MUSEOLOGY: WE ARE ALL MUSEOLOGISTS NOW
}

\section{David Anderson}

Sometimes I have this nightmare. I am in a world where certain people (museologists) have taken to themselves the right and power to identify and attribute meaning to objects on behalf of society. Also, the people with this power believe that their task is to tell people what they should know rather than to encourage them to think and learn for themselves about their past, present and future. Also, that museology is defined by museologists as what they do within the buildings they control - rather as if psychology were to be only what psychologists do in mental hospitals. Unfortunately, this particular nightmare happens to be some kind of reality as well.

The late Bill Shankley, the manager of Liverpool FC is reputed to have said «Football isn't a matter of life and death. It's more important than that». History, on the other hand, is a matter of life and death. We hardly need to have seen recent events in Northern Ireland and Yugoslavia (to name but two examples), to be reminded of the power which selective communal memory can exercise on contemporary societies.

Public understanding of the past - and present and future - is shaped by what is taught as well as what is personally experienced. Museums play a game with the public. It is the game of historical (or scientific, or aesthetic) interpretation and it is played with loaded dice. This is because museums, for the most part, present their exhibits, objects and texts only in support of their own interpretations.

In museums, we professionals often engage in wider academic debates in which ideas are tested against each other, critically and sometimes passionately. What we usually present to the public are positivist statements of fact and interpretation, without this critical element. We are too closely wedded to positivist ideology. Historians trained in the critical use of evidence as professionals present their conclusions to the public as established fact. Scientists, aware that science is culturally defined, too often present scientific knowledge as a product not a process. Such positivist illusions are our greatest 
68 fantasy. Our focus on materiality and our blurring of the boundaries between evidence and interpretation disguise our ideological intent.

In educating the public about the past, we should not give people historical "facts» but enable them to engage with history as a discipline. As individuals, and as members of society, we all need to be capable of thinking historically if we are to address the issues that confront us in our daily lives. Historical thinking requires us to put ourselves in the place of other human beings, and by doing so to define our own values and beliefs. It enables us to think critically and independently and to make informed judgements. It encourages us to question and to evaluate conflicting interpretations on the basis of evidence and to identify bias. It is the destroyer of historical myths. In the words of a publication produced some years ago by the then Department of Education and Science in the United Kingdom, "Thinking historically is not only one manifestation of an open society; it is also one of the guarantors of its continued existence»'

This is not the place to discuss in detail how we should acquire the capabilities required to think historically. It is, however, the place to note that museums for the most part make no attempt to educate the public to develop these skills, understandings and concepts. Much of what is done in museums is, in consequence, actively counter-historical and counter-educational. In life, it can often be what is not said or done that hurts us most, and here museums are also guilty. There are, as has been noted above, many competing acade- mic interpretations of the past. But these rarely gain exposure at a popular level least of all in museums.

There are also histories that are, in effect, products of the collective conscious historical and modern myths. Some people in the United Kingdom believe that there are crocodiles in the sewers of London and leopards on the loose in the English countryside. They believe in flying saucers. More dangerously, some (few, but a growing number) believe that the Holocaust never happened. In time, some of these modern myths may join the old English myth that in 1588 Francis Drake calmly continued to play bowls as the Spanish Armada sailed up the English Channel. Such myths may enter the collective historical consciousness, where they can exert a deep influence on public attitudes. This dimension of the human mind - which has been called the undergrowth of history - can often be as powerful in its effects as the official histories. More deep rooted, often passed on orally from generation to generation without exposure to critical enquiry, this collective consciousnesss can emerge at times of crisis to devastating effect. Museums have a responsibility to address these popular myths, as well as the official histories.

So much for the past, what of the future? If objective reality is an illusion, should museums instead make explicit their role as places of imagination and even dreaming? For dreaming is an essential part of what it means to be human. Too much of it can be dangerous - but presently museums have too little, despite being fundamentally utopian institutions. I come from a museum - the Victoria and Albert Museum - which is itself a product 


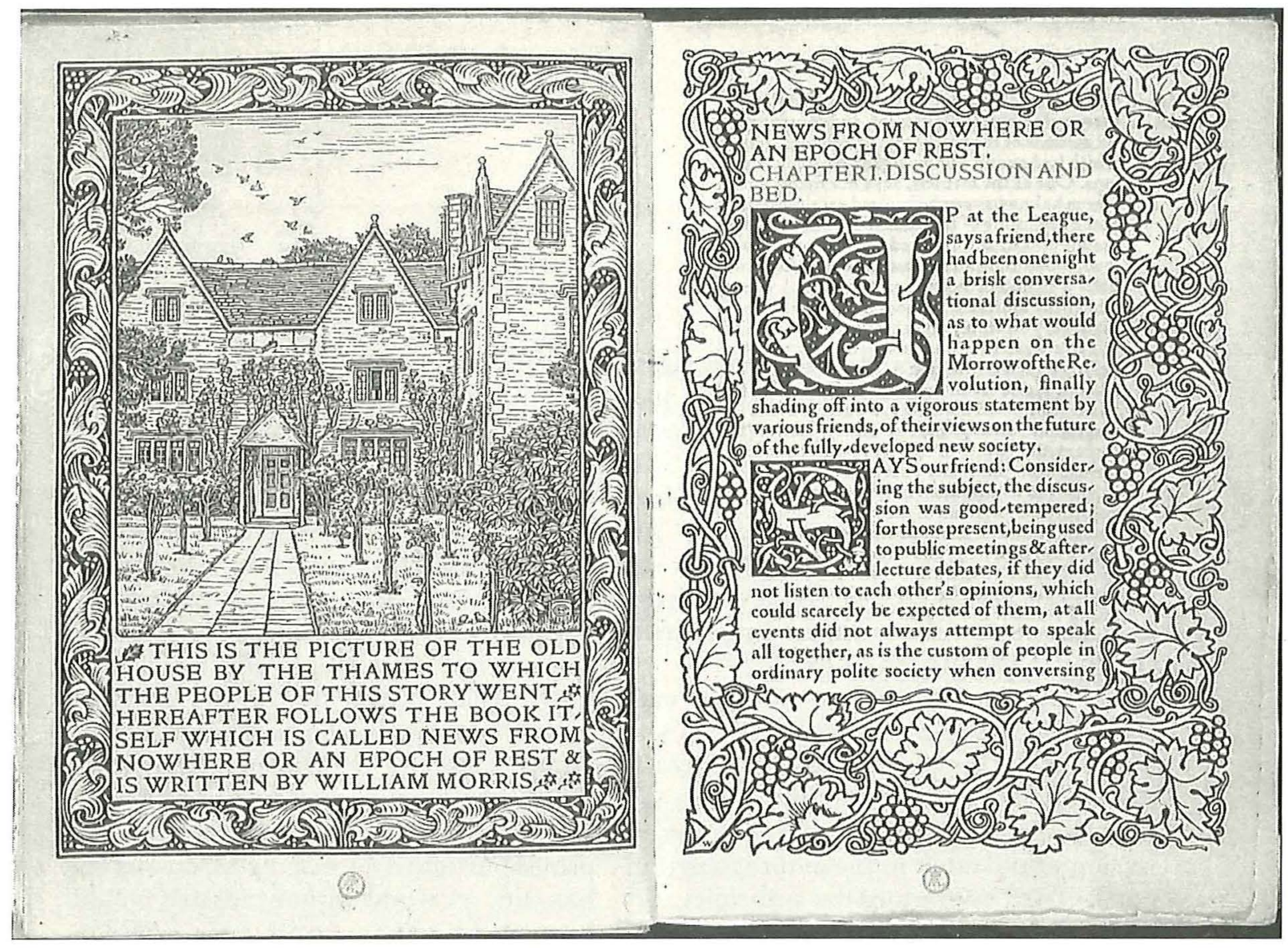

'News from Nowhere' by William Morris, Photograph courtesy of the Trustees of the V\&A.

of the great utopian tradition. William Morris, that inveterate utopian, was a seminal influence on the institution in its early years and is well represented in its collections.

Now it must be admitted that, after this initial involvement in the development of the V\&A, Morris became disillusioned with the museums and the education of his day.

The educational work at the South Kensington Museum (the forerunner of the V\&A and the Science Museum before they separated) in particular got short shrift:

"In times past, when what is (I suppose as a joke) called the Education Department at South Kensington was more or less mixed up with the Art Department, I have followed up a group through the wonders of drift of the art of past days, and perceived that their eyes never steadied once on any of these things, but that they brightened up at once when they came across a glass case in which the constituent parts of an analysed beef-steak were neatly arranged and labelled." ${ }^{2}$

Given Morris' scepticism in later life about museums, it is scarcely surprising to find that they play little part in his utopian visions. For Morris, the past - historic buildings, museums, even works of art and literature - were of use merely as a catalyst for the achievement of an ideal society. Once they had succeeded in their task, as in the future society he imagined in his arcadian utopian novel, News from Nowhere, they were by and large redundant. The young woman Clara exclaims «Books, books, always books, grandfather! 
When will you understand that after all it is the world we live in that interests us; the world of which we are a part, and which we can never love too much.» ${ }^{3}$ In view of what Morris had to say about the Museum's Education Department it is, perhaps, no surprise to discover that in News from Nowhere the South Kensington Museum seems to have disappeared entirely, to be replaced by woods. ${ }^{4}$

What has utopianism to do with our own work today? More, perhaps, than we might think. Utopias are usually removed either in time or in space (but not necessarily both) from ourselves - they are a version of the other in the anthropological sense. They are formed by principles, or rules, or social characteristics, or statements of belief which in the minds of their creators explain their perfection. They are stable and permanent. And they often offer a deliberate critique of contemporary conditions (and as such are closer to the here and now than their removal in time and space might initially suggest).

None of us, we may assume, have experienced utopia, but we fill our world (usually unconsciously) with micro-utopias hybrid entities that contain utopian features - collective as well as individual. Utopianism is everywhere - in almost everything we experience, as well as everything we think: statements and actions that reveal our concepts of the ideal society, and our attempts to enact them.

Museums are some of our society's most extensive micro-utopias. They remove their objects from their age and context displacement in time and space. They operate according to clear, rigidly imposed and rarely questioned codes for both staff and visitors which govern public thinking and behaviour. And they offer an implicit critique, in their "reality" and their order, of the society within which they exist. The journey of the object through acquisition, conservation, research and display is a ritual comparable to the journey of a soul through death and purgatory into paradise. The object, like the soul, is saved by museologists from the hell of extinction. The journey, is, of course, only one way.

For Isaiah Berlin, utopianism was "an almost natural distemper of the human mind ${ }^{5}$ Likewise, Karl Popper was a critic of the corrosive effects of its historicism. ${ }^{6}$ Yet it is perhaps a mistake to identify utopianism as entirely a vice. As Milan Simeka has said, "A world without utopias would be a world without social hope.» ${ }^{7}$ We in museums are used to keeping our eyes lowered. We believe we should avoid visions - we fear they will distract us from reality and dim our critical faculties. Of course, utopias are not "real" any more than dreams are «real». Yet they can be as necessary and important to the health of our souls, as dreams are to the health of our minds and bodies. Museums are the dreams and utopias created by museologists for our age; they may, of course, be nightmares and dystopias for their publics.

Ironically, it may be the intrusion of digital technologies which will make overt the dream-dimension of museums. Control of these technologies is shifting from the hands of technologists to those who work in the creative sectors of the economy. Now, the medium is emerging as an art form in its own right. Like museums, the digital media are becoming capable of creating dreams. More significantly (and in contrast to museums as 
they are at present) digital media are enabling people to shape their own dreams. In the kingdom of dreams, reality can only be imagined, but in future many more of us will have the power to dream publicly, through technology, and we may do so using museum resources.

If the "reality" offered by museums is illusory and museums are intrinsically utopian institutions which should abandon their positivist and materialist illusions, where does this leave the concept of truth? And how can an institution in which reality is only imagined, simultaneously encourage critical thinking about the past, present and future?

These apparent contradictions can only be resolved if we see that the problem lies with museology itself - or, rather, museo$\operatorname{logy}$ as it is now widely understood and practiced. Reality is not a product of the work of museologists. It is in the minds of our visitors - it is psychological, lived experience. It is not intrinsic to displays and the objects in them. Reality is created, but it is created by everyone; it is only within each individual that dreams and critical thinking can co-exist in harmony, as parts of that whole which defines what it is to be human.

The Dutch museologist Frans Schouten has drawn attention to the significance of Lewis Carroll's Paradox of the Map. The scholars of some country decided to draw the first map of their land. It was small, but they were pleased and decided to do another, on a larger scale. Again and again they increased the scale until finally they made a map as large as the country itself. As Schouten commented, "the closer we want to come to reality, the more we have to violate it. Attempts to finalise this pro- cess can even result in the musealization of the whole environment». ${ }^{8}$ Truth is about meaning, not appearance. Cultural transformation, not replication of reality, is our business. We cannot make the past real, but we can equip the public to engage in the processes of historical thinking and to develop a critical awareness of the historical interpretations of others, including those of museums. We have similar responsibilities to engage people in the processes of scientific and aesthetic thinking and practice.

For museums to attempt to present objective reality is, then, a futile exercise, doomed to failure through its own contradictions. The work of museums is, instead, to encourage and enable people to seek truth for themselves. It is a task which must be undertaken in humility, and it is one which demands of us changes in both philosophy and practice. We must redefine the relationship between staff and public to embrace the concept of "common sense» as formulated by the Scottish philosopher George Davie, in which the expertise of professionals is accountable to, and dependent upon, the common understanding of the community." It is a task not of transmission of information but of cultural education - not of communicating facts but of encouraging and enabling people to develop the skills of making meaning for themselves, individually and socially.

This is not an unrealistic objective. Museum are not classrooms. They are resource-rich, sociable, experiential, public spaces. They are ideal centres for personal learning. There is now a vast amount of research to support the view that learning which is informal or self-planned, and 
72 developed through social networks rather than formal education, is the bedrock upon which all other learning is constructed. This self-directed learning represents «a parallel universe» of learning, according to the adult educator Stephen Brookfield, which lies beyond the formal education system..$^{10}$ The twentieth century has been the century of the classroom, but, as a consequence in part of the development of personal digital media, the twenty-first century will be the century of personal learning - and thus also of public learning through museums and other cultural institutions, if only they will accept this new educational role.

The most effective learning is that which is active and participatory, and it is vital that the experience of such learning in museums begins in childhood if it is to become a lifelong process. The research of educational psychologist Howard Gardner has led him to conclude that if children do not get the opportunity to engage actively in the arts, as creators, performers, audience members and critics, certainly by the age of ten and perhaps even by the age of seven, their development will be restricted and they are less likely to participate in the arts as adults." When it comes to participation in the experiences museums can offer, the ultimate responsibility for educating the public in these particular skills lies ultimately with ourselves. We cannot assume it will be done by schools and other educational institutions; in fact, we know from present evidence that they cannot and will not do it. It is us alone who can help the public to learn to think, feel and dream through museums, and we need to start early.

The Mughal Tent project at the V\&A is an example of an educational initiative which threw open the doors of the Museum to a significant but under-represented group of women from the South Asian community, many of whom had never visited a museum before. Inspired by the V\&A's South Asian collections and the example of the V\&A's South Asian Arts Eduction Officer, the late Shireen Akbar, groups of women from across the country drew together the threads of their own experience to create panels of their own designs which are of extraordinary quality, beauty and individuality. An older woman saved from oblivion a rare stitch from Sind province in India; younger girls at college included in their designs their aspirations for their futures. The project changed the lives of many and has now spread worldwide.

There were a number of reasons for the project's success. These include its commitment to social change, a people-based mission closely related to participant needs, and development through strong existing social networks. Above all, the project is an example of personal learning, in which participants, working in their communities as well as in the Museum, shared in the decision-making process. The project culminated in the exhibition Shamiana: the Mughal Tent, which was displayed in the V\&A's Pirelli Gardens in the summer of $1997 .^{12}$

There have been suggestions that the project should move into digital space, so that many more groups could contribute to it. The challenge for digital media would be to provide a social, authentic and multi-sensory experience comparable to that provided by the project so far. Digital projects in museums will need to 
Detail from

'Freedom for Life' by Tower Hamlets Youth Group, Tower Hamlets College of Further Education, Tower Hamlets, London, 1993. Photograph courtesy of the Trustees of the Ver A.

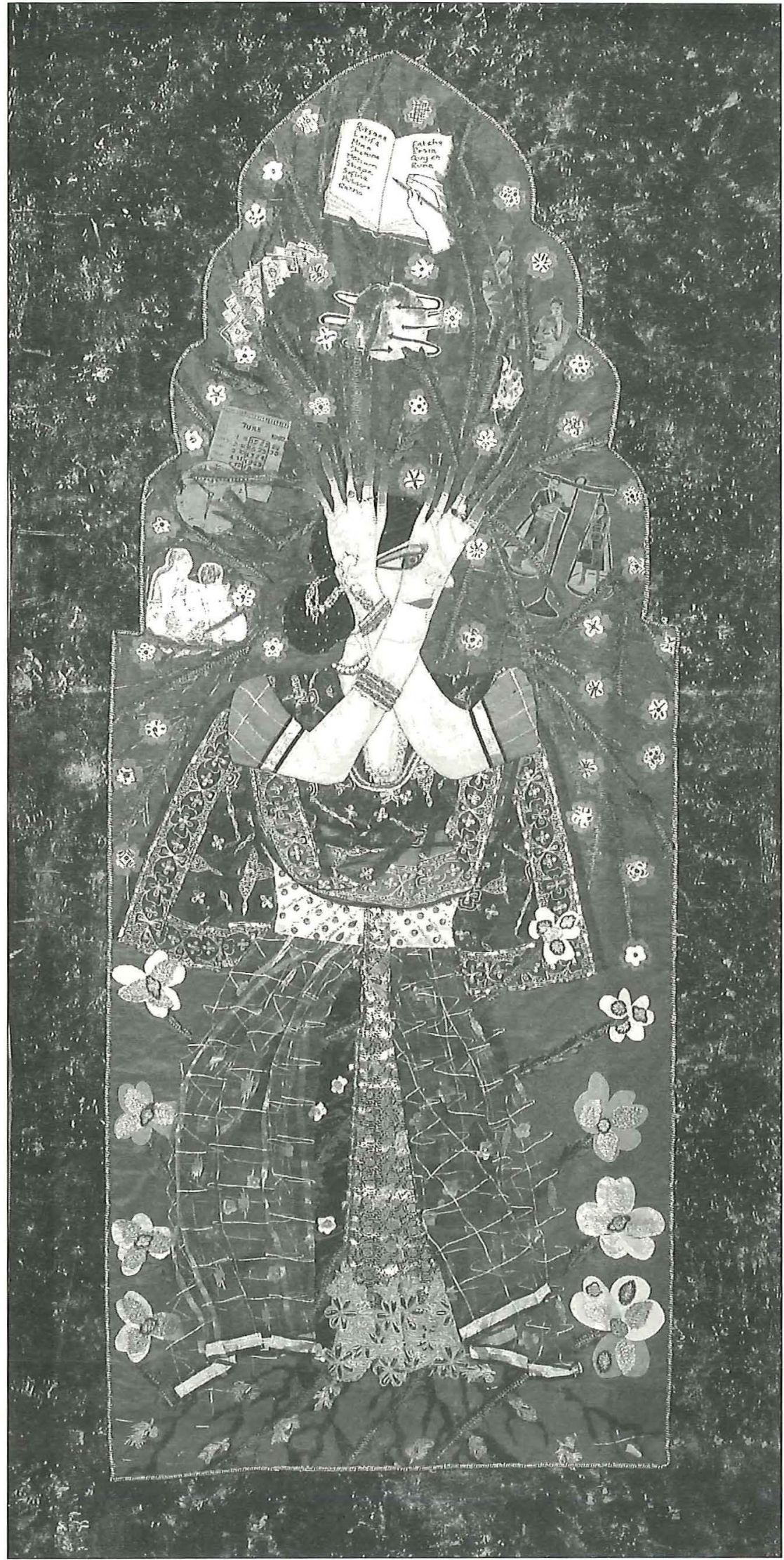




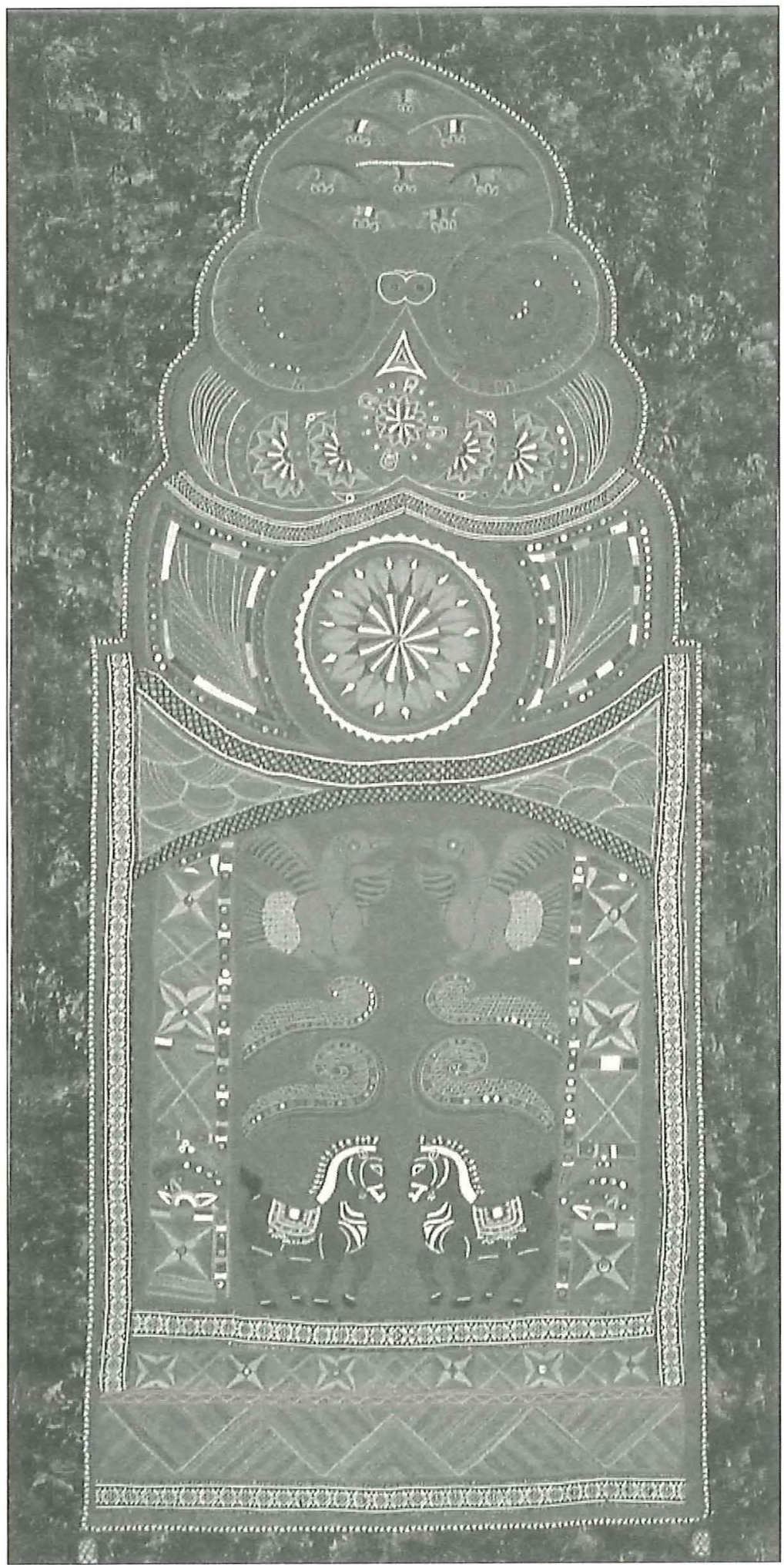

'Tapestries of Life' by Madras Craft Foundation, Madras, India, 1993. Photograph courtesy of the Trustees of the VEA. 
be appropriate to their medium rather than imitations of existing museum activities.

We have had too many «new» museologies that are in effect restatements of the old - that re-assert, as Peter Vergo did in 1989 , that museology is "the study of museums, their history and underlying philosophy," a definition which emphasises yet again the primacy of the institution. ${ }^{13}$ Vergo did go on to define "new» museology as " a state of widespread dissatisfaction with the 'old' museology", by which he meant that new museology should be concerned more with processes and issues and less with methods, but this is not enough.

A far more radical philosophical shift is now required, one that is based on the principle that museology is concerned with people, not institutions. Specifically, I suggest museology should be defined as the study of the attribution by people of significance to and learning from, the cultural and natural resources of their own society and those of other times and societies. This engagement may, or may not, take place in a museum, because museology is concerned with the human mind, and its purpose is one of individual and community learning and development, drawing energy and inspiration from the cultural resources of the community itself as well as those of any institution. It is the public, not museums and their staff, who make culture; hence it is the making of meaning and value by everyone in society that is the means as well as the end of museology. Museology is a way of thinking, which anyone can acquire. It is possible to imagine - and perhaps still find today - societies without museums which are still strong in those things museology was established to develop.

There is, of course, a political dimension to this philosophical position. It concerns the nature of the society we wish to create. A society in which museologists act as the high priests of culture, creating all the exhibitions, writing all the texts, and deciding the purposes and content of their educational work, with their communities standing on the outside looking in, is one which has no place in a democracy in which the "common sense» is valued. If this were to be the practice of museology, we should indeed follow the example of William Morris and return the museums to woodlands where children can play.

Sometimes I have a dream. It is that we are all museologists now.

\section{NOTES}

1. Department of Education and Science, History in the Primary and Secondary Years: An HMI View, DES, London, 1985, p.39. The methodologies of development of historical thinking in museums are developed by me in «Learning history in museums» in The International Journal of Museum Management and Curatorship, London, 1989,( 8) pp.357-368.

2. William Morris, "The Society of the Future», reproduced in The Political Writings of William Morris, Lawrence and Wishart, London, 1973, p.199. The theme of utopianism in museums was explored in my unpublished lecture «Utopianism in museums,» delivered at the International Conference on Scientific Literacy at the Science Museum, London, on 9 November 1994.

3. William Morris, News from Nowhere, Penguin Books, London, 1993, p175.

4. Ibid, p.64. 
76 5. Cited in Krishnan Kumar, "The End of Socialism? The End of Utopia? The End of History?» in Utopias and the Millennium, edited by Krishnan Kumar and Stephen Bann, Reaktion Books, London, 1993, p.67.

6. Ibid, p.66.

7. Ibid, p.75.

8. Frans Schouten, «The Paradox of the Map: Semiotics and Museum Education," in Museum Management and Curatorship, ButterworthHeinemann, London, 1992 (11)p. 285. The subject of reality and replication in museums was the subject of a panel discussion at the UK Museums Association's Annual Conference in Harrogate in September 1996, subsequently published as "Reality and replica» in Museum and Exhibition Design, Museum and Exhibition Designer Group, London,1997, pp.11-14

9. George Davie, «The Social Significance of the Philosophy of Common Sense», in The Scottish Enlightenment and Other Essays, Polygon, (Edinburgh), 1991 Pp. 51-85.

10. Stephen Brookfield's research on the "parallel universe» of self-directed learning is summarised in Adult Learners, Adult Education and the Community, Open University Press, Milton Keynes, 1983, and Understanding and Facilitating Adult Learning, Jossey Bass, San Francisco, 1986.

11. For a discussion on the debate on arts and developmental psychology, including Gardner's theories, see David H.

Hargreaves, "Developmental Psychology and the Arts,» in David H. Hargreaves (ed), Children and the Arts, Milton Keynes, Open University Press, pp.4-21.

12. Shireen Akbar,»Multicultural Education: The Mughal Tent Projet at the Victoria and Albert Museum," in Alan Chadwick and Annette Stannett (eds.), Museums and the Education of Adults, National Institute of Adult Continuing Education, Leicester, 1995, pp.84-91.
13. Peter Vergo, «Introduction» in Peter Vergo (ed), The New Museology, Reaktion Books, London, 1989, pp 1-5.

This paper was given June 211997 in the seminar Museums, society and museology, arranged by the Danish Museumshojskolen, at Vester Vedsted on Jutland.

David Anderson is Head of Education at the Victoria and Albert Museum, and author of the UK' government report on museum education, A Common Wealth: Museums and Learning in the United Kingdom, Department of National Heritage. London, 1997.

Adr: Victoria \& Albert Museum, South Kensington, London SW72RL, UK

Fax +441719388500 